FACTA UNIVERSITATIS

Series: Philosophy, Sociology, Psychology and History Vol. 20, № 1, 2021, pp. 73 - 86

https://doi.org/10.22190/FUPSPH2101073M

Review Paper

\title{
THE ENVIRONMENT - A TERRA INCOGNITA FOR MOST SOCIOLOGISTS IN SERBIA
}

\author{
UDC 316.334.5(497.11)
}

\section{Vesna Miltojević}

University of Niš, Faculty of Occupational Safety, Serbia

\begin{abstract}
The issue of future societal development has captured the attention of scientists and experts from different fields and it is increasingly associated with environmental capacity and quality. The reach and the topicality of the issue were identified more than 40 years ago, while the solution materialized years later as a new paradigm of societal development - sustainable development. Considering the subject of study of sociology and its significance for steering societal development, this author was faced with the question of how and to what extent Serbian sociologists deal in their theoretical and empirical studies with the nature-society relationship and with sustainable development as a globally accepted development model. The discussion in this paper is based on the articles published in leading Serbian national journals in the fields of sociology and multidisciplinary sciences. The first findings reveal that sociologists less frequently deal with the environment and sustainable development than other social scientists, such as jurists, economists, psychologists, pedagogists, or andragologists. In this author's opinion, one of the reasons for the relative marginalization of sociological research on the society-environment relationship is the relatively belated inclusion of specialized sociological disciplines such as social ecology or environmental sociology in the curricula of sociology academic programmes.
\end{abstract}

Key words: society, environment, sustainable development, sociologists, periodicals.

\section{INTRODUCTION}

Until the mid- $20^{\text {th }}$ century, the prevalent view among scientists from various fields was that of an infinite societal growth and progress accompanied by the glorification of the power of science and technology. However, indications of the limited amount of natural resources and the disrupted ecological balance as the limiting factors of societal development led to a different perception of the nature-society relationship. Facing the

Received October 26, 2020 / November 12, 2020

Corresponding author: Vesna Miltojević

University of Niš, Faculty of Occupational Safety, Čarnojevića 10a, 18000 Niš, Serbia

E-mail: vesna.miltojevic@znrfak.ni.ac.rs 
issues of social progress, which were also associated with growing environmental issues, sociologists, initially only American sociologists, began to explore society and nature as a unity, or a socio-ecological system (SES).

Discussions about the necessity of establishing a new sociological discipline that would study the SES began in the 1980s, even though social ecology had been established several decades earlier within the Chicago School. In their examinations of metropolitan issues, Robert E. Park, Ernest W. Burgess, Roderick D. McKenzie, and Louis Wirth indicated that the differentiation between what is natural and what is social was no longer possible and that social segregation, rising crime rates, ethnic conflicts, and deteriorating health of the population were consequences of a disbalance between the natural and the societal (see e.g. McKenzie 1924; Park 1915).

\subsection{Sociologists' interest in studying SES relations}

The increasingly pronounced disruption of the ecological balance is commonly associated with the development of industrial civilization, even though industrial development accompanied societal development throughout human history. However, owing to scientific and technological development, the natural potential was turned into natural resources and the human lifespan increased, contributing to environmental pollution, which threatens all life on earth. It was found that natural resources are limited and that unlimited growth is impossible with the constant global population rise, the development of profit-oriented technology, and the anthropocentric worldview. Accordingly, phenomena including demographic explosion, lack of natural resources and energy, and disruption of the ecological balance, referring to the pollution, endangerment, and destruction of ecosystems, were identified as the anthropogenic causes of the ecological crisis. Almost simultaneously, in the second half of the $20^{\text {th }}$ century, biologists, rather than sociologists, specifically Rachel Carson, Barry Commoner, Paul and Anne Ehrlich, and Garrett Hardin put the spotlight on the growing environmental issues, which can be and which are a limiting factor for societal development. Their publications drew attention to various issues, such as the harmful effect of using chemicals in agriculture (Carson 1962), the connection and interdependence of nature and society (Commoner 1971), and population growth as one cause of environmental issues (Ehrlich, Ehrlich 1970; Hardin 1968). Their work also influenced public opinion and incited social movements, politicians, as well as some Western sociologists to bring into focus the question of how we should perceive the interdependence and mutual influence of nature and society.

The encouragement to place the environment in a sociological perspective in the context of societal development was provided by international associations of sociologists, the $\mathrm{UN}$, and the research conducted within the Club of Rome.

The seventh World Congress of Sociology in Varna (1970) launched the initiative to establish the Research Committee on Social Ecology - RC24 with an aim of adding a sociological perspective to environmental issues. The International Sociological Association (ISA) officially recognized the Committee in 1971 and appointed Mattei Dogan as the first provisional president of the Committee. Several years later (1974), at the Toronto World Congress, RC24 had more than 100 members and established several task forces: Spatial Differentiation, Level of Aggregations, Area Analysis, Political Ecology, and Pollution and Environment (ISA 1982). 
There were many difficulties with how to organize sociological research of the environment. The task forces changed and two years after the official establishment of RC24 and its task forces, the task forces were reorganized as follows: Theory and Methodology in Ecological Research, Ecological Analysis and Social Change, Microecology, Ecological Aspects of the Quality of Life, and The Automobile and the City. The Research Committee on Social Ecology was trying to respond to the contemporary environmental issues through continuous formation of new task groups, leading to a name change in 1992 into the Research Committee on Environment and Society.

The growing interest of sociologists to explore the society-environment relationship is evidenced by the number of sessions and papers presented at ISA congresses. For instance, immediately after the establishment of RC24, at the eighth World Congress of Sociology in Toronto (1974), sociologists presented 31 papers by one or more authors within four sessions; at the most recent, nineteenth World Congress in Toronto (2018), there were 20 sessions with over 120 presented papers (ISA 1982, 10-11; ISA 2018, 246-253). The awareness that sociologists had neglected the "habitat" and that the primary considerations of the social environment had suppressed the consideration of physical circumstances (Michelson 1976, 17) led to the first publications that encouraged sociologists to consider SES relationships in a different manner ${ }^{1}$ and to initiate the creation of a new sociological discipline.

Of equal significance is the publication of the paper by W. R. Catton and R. E. Dunlap, Environmental Sociology: A New Paradigm (February 1978), who state that the reasons for insufficient research of the nature-society relationship lie in the Dominant Western Worldview, a fundamental anthropocentrism underlying all theoretical claims of modern sociology, ${ }^{2}$ as well as the widely accepted Human Exceptionalism Paradigm (HEP). ${ }^{3}$ They advocated the introduction of the New Environmental Paradigm (NEP) in sociology, ${ }^{4}$ which would enable the creation of a new sociological discipline, Environmental sociology, ${ }^{5}$ in

\footnotetext{
${ }^{1}$ E.g. M. Dogan and S. Rokkan, Social Ecology, 1974; Z. Mlinar and H. Teune (eds.), The Social Ecology of Change. From equilibrium to Development, 1978; L. K. Milbrath, Quality of Life: Values, Lifestyles and Beliefs, 1980 (ISA 1982, 11).

2 "Not only have sociologists been too unmindful of the fact that our society derived special qualities from past abundance; the heritage of abundance has made it difficult for most sociologists to perceive the possibility of an era of uncontrived scarcity" (Catton and Dunlap 1978, 43). Dunlap later listed the four postulates of the Dominant Western Worldview: „DWW1 People are fundamentally different from all other creatures on Earth, over which they dominion. DWW2 People are masters of their destiny; they can choose their goals and learn to do whatever is necessary to achieve them. DWW3 The world is vast, and thus provides unlimited opportunities for humans. DWW4 The history of humanity is one of progress; for every problem there is a solution, and thus progress need never cease" (Dunlap 2002, 333).

${ }^{3}$ The four postulates of HEP: “(1) Humans are unique among the earth's creatures, for they have culture. (2) Culture can vary almost infinitely and can change much more rapidly than biological traits. (3) Thus, many human differences are socially induced rather than inborn, they can be socially altered, and inconvenient differences can be eliminated. (4) Thus, also, cultural accumulation means that progress can continue without limit, making all social problems ultimately soluble" (Catton, Dunlap 1978, 42-43; see also Dunlap 2002, 333).

4 “(1) Human beings are but one species among the many that are interdependently involved in the biotic communities that shape our social life. (2) Intricate linkages of cause and effect and feedback in the web of nature produce many unintended consequences from purposive human action. (3) The world is finite, so there are potent physical and biological limits constraining economic growth, social progress, and other societal phenomena" (Catton, Dunlap 1978, 45).

${ }^{5}$ In Serbia, the efforts to establish a new sociological discipline that would study the SES relationships resulted in the creation of two scientific and educational disciplines - Social Ecology and Environmental Sociology. Their subjects of research are almost identical (see Marković 2015 and Pušić 2001). The differences in the
} 
which the SES relationships would be treated differently, through the interaction between society and nature. ${ }^{6}$ According to Dunlap, there are four reasons why the NEP should be accepted: "While humans have exceptional characteristics (culture, technology, and so on), they remain one among many species that are inter-dependently involved in the global ecosystem. Humans live in and are dependent on a finite biophysical environment that imposes potent physical and biological restraints on human affairs. Although the inventiveness of humans and the powers derived therefrom may seem for a while to extend carrying capacity limits, ecological laws cannot be repealed" (Dunlap 2002, 333).

The European Sociological Association (ESA) also spurred sociologists to tackle the issues in the SES by forming the Research Network Environment and Society - RN12. The importance of sociological considerations of SES issues is validated by the fact that, as early as at the First Conference in Vienna in 1992, a topic at one of the sessions involved environmental issues (ESA 1992), and that a session at the very next conference (1995) was entitled Ecology in Europe (ESA, 1995). At the most recent conference, held in Athens in 2017, RN12 had 26 sessions with four to five papers each (Gross 2017).

At the UN conference in Stockholm (1972), dedicated to the human environment, the environment was defined as a set of natural and social components and the connection between natural capacities and societal development was emphasized. The report by Barbara Ward and René Dubos entitled Only One Earth, adopted at the UN conference, not only indicates the connections within the SES from a scientific standpoint, but also stresses the necessity of accepting responsibility for the survival of humankind and the entire planet. Accordingly, revealing a link between the environment and societal development provides an opportunity for a new study field in sociology. Equally instrumental are the conferences dedicated to the environment and sustainable development in Rio de Janeiro (1992 and 2012) and Johannesburg (2002). The interest of sociologists to study the SES was particularly sparked after the adoption of the concept of sustainable development (SD) at the 1992 UN Conference on Environment and Development in Rio de Janeiro (1992), which was based on the Brundtland Report, published in 1987 under the title Our Common Future, identifying the three pillars of sustainable development (economic, social, and environmental) and emphasizing the idea of intergenerational equity.

The reports by the Club of Rome also significantly influenced the sociological considerations of environmental issues. In 1968, industrialist Aurelio Peccei and Scottish scientist Alexander King, concerned over the rapid societal development, environmental degradation, and differences in the degree of development between different countries, gathered over 30 scientists from various fields and initiated discussions that were supposed to lead to a proper consideration of the nature-society relationship. For that purpose, thanks to the efforts from Jay Forrester, a computer model, called the World3 model, was developed and used by a group of MIT scientists to write a report entitled The Limits to Growth, which indicated the unsustainability of continuous societal growth. The authors of the report, Donella H. Meadows, Dennis L. Meadows, Jørgen Randers, and William W. Behrens III, investigated the relationship between population, industrial growth, agricultural production, and environmental pollution, concluding that the limits

names of the disciplines can be explained by the influence of North American, Russian, and Frankfurt sociology and by the translation of the noun-adjective pair environment/environmental.

${ }^{6}$ Catton and Dunlap's opinion that the roots of the new sociological discipline cannot be found among the classical sociologists sparked a heated exchange with F. H. Buttel, who published a paper under the same title in 1978, refuting their claims (Buttel, 1978; see also Pajvančić-Cizelj 2015, 2-24). 
to growth are determined by the material and energy resources and the capacity of the planet to absorb waste. They also concluded that exponential economic growth exhausts resources and that if the current growth trends in the population, industry, food production, and consumption of natural resources were to continue unchanged, a rapid decline would ensue around 2020. In order to achieve ecological and economic stability, it is necessary to do the following: stabilize population growth by approximating the birth and mortality rates; limit the consumption of natural resources to the 1970 level; restructure national income from material to non-material services, healthcare, education, and so on; decrease environmental pollution to $1 / 4$ of the 1970 level; extend the period of using material resources for long-term exploitation; and invest in soil quality improvement (Meadows, Meadows, Randers \& Behrens III 1974). Their predictions and proposed measures triggered a plethora of reactions, followed by a number of less pessimistic reports. The first of those reports, as well as the others that ensued, ${ }^{7}$ might be considered stimulatory for sociologists, as they stressed specific problems of societal development, associating them with global inequalities, population growth, industrial growth, and environmental condition and capacity.

In the second half of the $20^{\text {th }}$ century, sociologists from former Yugoslavia were not far behind the Western sociologists in terms of actively promoting different views of SES relationships. Zdravko Mlinar actively participated in the work of RC24, being appointed a Board member at the Toronto congress in 1974, and a Vice-President in 1979. In 1974, the Eighth Scientific Conference of Sociologists of Yugoslavia took place, with Industrialization and Protection of the Human Environment (Ecological Issues in Our Country) being one of the topics. In 1976, an international workshop entitled "Comparative ecological analysis of social changes" was held in Ljubljana, chaired by Zdravko Mlinar, resulting in 67 presented papers. In the same year, the term human environment found its way into the Small Lexicon of Self-Managers (Serb. Mali leksikon samoupravljača), while 1982 saw the first publications to consider environmental issues from a sociological perspective. Likewise, during the 1980s, the first textbooks entitled Social Ecology were published, one by professor Danilo Ž. Marković (1986) in Belgrade and the other by professor Ivan Cifrić (1989) in Zagreb.

In this author's opinion, since the 1990s and the dissolution of former Yugoslavia, the environment has been relegated to the sidelines among Serbian sociologists. The conferences held by two Serbian sociological associations were primarily dedicated to the 'burning' issues in our society (the dissolution of Yugoslavia, the civil war aftermath, transitional processes, etc.), which suggests that Serbian sociologists, or at least the majority of them, as opposed to foreign sociologists, still believe that environmental issues should be tackled by someone else. If one accepts that periodicals are "a reflection of the spirit of the times" (Golubović 1989, 207) and "one of the most significant expressions of the institutional and professional development of a science" (Bogdanović 1989, 215), and that "the versatility of content and ideas on which the articles in scientific journals are focused paints a picture of the maturation stages of a science" (Petrović J. 2012, 960), it is then justified to turn to social science journals to determine how much Serbian sociologists theoretically and empirically consider and investigate the SES relationships and sustainable development.

\footnotetext{
${ }^{7}$ The following seem to be the most relevant to the present discussion: Mankind at the Turning Point (1975); Rio: Reshaping the International Order (1977); Beyond the Age of Waste (1978); Beyond the Limit to Growth (1989); Beyond the limits: Global collapse or a sustainable future (1992); The Limits to Growth: The 30-year Update (2004); and 2052: A Global Forecast for the Next Forty Years (2012).
} 


\section{MATERIAL AND METHOD}

This research focuses on the 1991-2019 issues of Sociologija (Sociology) and Sociološki pregled (Sociological Review), as the leading Serbian sociological journals, as well as Zbornik Matice srpske za društvene nauke (Matica Srpska Journal of Social Sciences) and Teme (Themes), as the leading journals in the field of interdisciplinary sciences. $^{8}$

The research was conducted in several steps. The first step was to separate the published papers dealing with SES based on their titles, abstracts, and key words in order to determine the share of papers that deal with these issues. Based on the authors' affiliations, with additional inspection, we selected the papers written by sociologists and $\mathrm{PhD}$ holders from other fields who teach sociological courses at Serbian universities. The purpose was to determine the share of papers written by sociologists within the corpus of previously selected papers. The following step was to analyze the selected papers' content in order to identify their thematic focus and the key topics that the sociologists tackled within the nature-society relationship. The papers selected for analysis had to include at least one of the following terms: environment and society; environmental awareness; environmental issues/problems; environmental policy; environmental management; environmental risks; sustainable development; quality of life and environment; environmental needs, bioethics; ecocentrism; agriculture and sustainable development; and sustainable city.

\section{RESULTS AND DISCUSSION}

\subsection{A quantitative analysis of SES papers published in Serbian journals}

From 1991 to 2019, a total of 3,906 papers were published in the four analyzed Serbian journals (both original research and review papers), of which only $2.87 \%$ dealt with the various aspects of the nature-society relationship (sociological, legal, psychological, economic, etc.), while less than a half (39.28\%) were papers by sociologists. Regardless of the finding that almost one in three published papers, whether theoretically or empirically examining the SES relationships including SD, was written by sociologists, there are at least two reasons such a result cannot be considered satisfactory. First, the research involved two sociological journals, one of which had an issue that was thematically oriented toward environmental protection and sustainable development. Second, the number of papers dealing with SES relationships and SD published by sociologists in the two sociological journals was $0.28 \%$ higher than the number of similar papers published in the two journals of interdisciplinary studies.

The analysis of published papers in all four journals revealed that the total number of papers was increasing but that the number of sociological papers was decreasing. From 1991 to 2000, the fewest published papers were on the nature-society issues, but $50 \%$ of those were written by sociologists. In the following decade (2001-2010), the number of papers tripled, but now the share of papers by sociologists was reduced to $42.31 \%$. Even though the last analyzed decade (2011-2020) is still ongoing, there is a noticeable increase of papers that discuss the SES relationships and SD from the perspective of

\footnotetext{
${ }^{8}$ Since 2008, the journals are categorized as M24 - journals of international significance verified by a special decision - in the official list of journals by the Ministry of Education, Science and Technological Development of the Republic of Serbia.
} 
disciplines other than sociology. The total number of papers increased by more than two and a half times compared to the previous decade and more than sevenfold compared to the first analyzed decade, but the share of sociological papers was considerably reduced to only $36.84 \%$ (see Fig. 1). It would be justified to assume that this share will not significantly increase and reach the shares from the previous two decades by the end of the current decade.

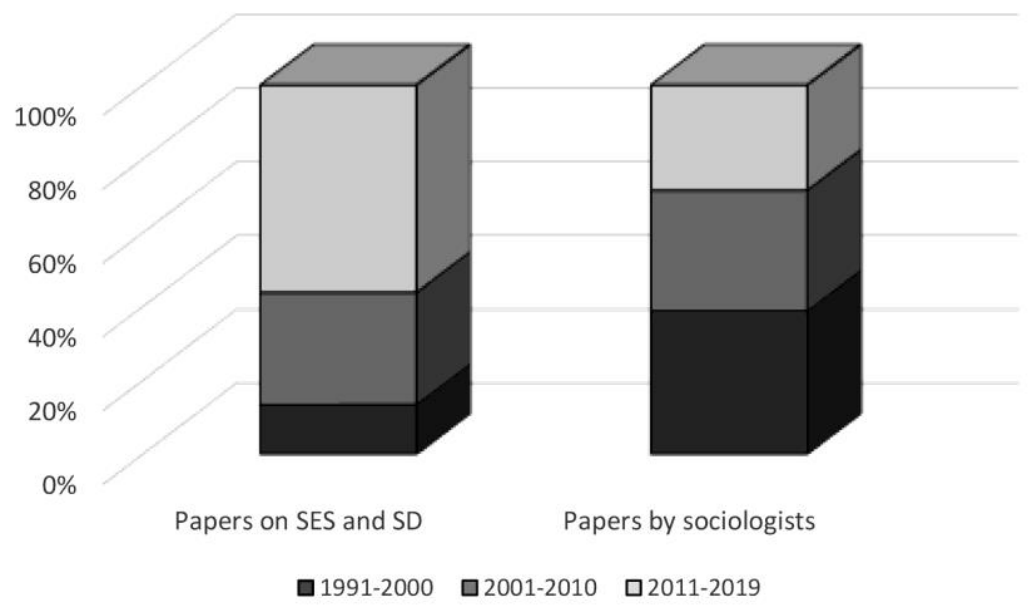

Fig. 1 Papers focusing on SES and SD in four leading Serbian journals

The by-decade analysis has shown that the number of papers dealing with SES and SD issues in interdisciplinary journals increased more than fivefold during the current decade $(5.08 \%)$ compared to the first decade $(0.96 \%)$ and almost tripled compared to the second decade $(2.95 \%)$. The number also increased in sociological journals compared to the first and second decade by more than double and double, respectively $(1.05 \%$ and $1.33 \%$ vs. $2.64 \%$ ). Such results can be explained by the fact that the papers in sociological journals are predominantly authored by sociologists.

Another noteworthy finding is that there were no papers dealing with the SES and SD in any of the journals during the seven studied years, specifically in 1992, 1993, 1997, 1998, 2001, 2003, and 2005.

A total of 1,631 papers were published in the two sociological papers, Sociologija and Sociološki pregled, 840 in the former and 791 in the latter. Out of that number, only $1.29 \%$ were papers dealing with the SES and SD and $85.71 \%$ of these were written by sociologists. A third of all published papers on these topics were published in Sociologija in 2012. Yet, these journals together had zero published papers on environmental topics for more than years. In accordance with the socio-economic and political situation in Serbia (the dissolution of Yugoslavia, civil war, and transition), politics and the economy were the chief interests of sociologists, as evidenced by their publications (see also Vuletić and Stanojević 2012, 47-68 and Petrović and Miltojević 2019, 112-128).

The first volume of Sociologija for 2012 was dedicated to the topic of SES issues and $\mathrm{SD}$, or to "one of the youngest sociological disciplines - environmental sociology" (Petrović M., 2012, p. 1). The analysis revealed that $60 \%$ of the papers in this journal were theoretical discussions about the different aspects of SES relationships and SD from 
the perspective of urban sociology, as well as analyses of biopolitics. The empirical papers presented research results about the degree of citizens' environmental awareness and involvement in dealing with environmental issues in urban and rural areas.

All papers published in the Sociološki pregled were theoretical, discussing topics such as the establishment of the sociological discipline studying the nature-society relationship, sustainable development including urban sustainable development, deep ecology, management of international environmental issues, environmental activism, and climate change.

The two interdisciplinary social science journals contained a total of 2,275 papers, of which $3.69 \%$ discussed the nature-society relationship and sustainable development. Less than a third of those papers were written by sociologists $(27.38 \%)$.

The data show that significantly fewer papers were published in the Zbornik Matice srpske za društvene nauke - out of 900 papers, $1.55 \%$ discuss the SES relationships and SD. Out of the total number of papers dealing with SES relationships and SD, $14.28 \%$ were written by sociologists, on the topics of environmental protection, sustainable development, and environmental awareness.

In the journal Teme, the share of the papers dealing with theoretical and empirical SES issues and SD was almost five times larger than in the Zbornik Matice srpske za društvene nauke. Out of the total of 1,373 published papers in Teme, $5.09 \%$ were papers dedicated to the said topics, less than a third of which were written by sociologists. It must be noted that the editorial staff of Teme were sufficiently attuned to the circumstances to recognize the topicality of environmental issues and sustainable development, which is why they dedicated separate journal issues to these topics in 2002, 2006, 2012, and 2019. The topics discussed in the papers published in Teme included urban development and ecology, sustainable development, environmental awareness, as well as the examination of the relationship between globalization and ecological crisis, environmental ethics, bioethics, gender, and climate change.

Even though the data indicate that the share of papers increased over the analyzed period in the sociological and interdisciplinary journals, in terms of the number of sociologists who teach or used to teach at sociology departments of the four Serbian faculties of philosophy, it would appear that relatively few of them dealt with environmental topics, beginning only around 2012. The affiliations of the authors of the analyzed papers indicate that environmental topics were prevalently covered by sociologists who teach at other faculties or departments not specializing in sociology, as only $39.58 \%$ of the authors came from the specialized sociology departments at the faculties of philosophy.

\subsection{Key topics of sociological studies}

Compared to the results obtained in the present research, the data on papers published by sociologists in foreign journals were considerably different. Sociologists' interest in studying the nature-society relationship began much earlier in foreign journals, in the 1980s, with the first considerations of establishing a separate sociological discipline, and found its footing after 1990, especially after the 1992 UN Conference on Environment and Development in Rio de Janeiro (Scott, Johnson, 2017). In Serbia, the absence of discussions on establishing a sociological discipline that would study the nature-society relationship, coupled with the sporadic theoretical and empirical studies published in the analyzed domestic journals from 1991 to 2019, only confirm the opinion of Mina Petrović that 
the new sociological discipline in Serbia, as well as in other "post-socialist academic communities", is "in its infancy" (Petrović M. 2012, 4).

As regards the results of the studies in papers published in foreign journals, there is a difference in both the time at which sociologists began to deal with SES issues and the topics the authors discussed. ${ }^{9}$ Our analysis of the papers published in domestic journals identified nine key topics discussed by Serbian sociologists: sustainable development; urban development and the environment; environmental policy; environmental issues and society; environmental awareness and environmental activism; ethics and the environment; climate change; rural development and the environment; and environmental culture (Fig. 2).

Sustainable development and environmental issues and society were the two most frequent topics in domestic journals over the analyzed period. The authors critically examined the model of SD at the macro, socio-cultural, political, economic and technological, and ecological and demographic level and stressed the importance of accepting the four-pillar model of SD, the connections between globalization, neoliberalism, ethics, and SD, and between SD and urban/rural development (see e.g. Magdalenić 2010; Miltojević 2011; Mitrović V. 2012; Pušić 2012 and 2013). Environmental issues and how they affect society were the focus of both theoretical and empirical studies, wherein sociologists discussed the various causes and effects of the ecological crisis, emphasizing and juxtaposing the different viewpoints on the issue (see e.g. Čikić 2012). In their examination of the nature-society relationship, the authors mostly highlighted the impact of globalization, scientific and technological development, the economy, and the dominant systems of values as the major causes of disturbing the balance in the system (see e.g. Milošević 1996; Marković 2002; Vuković 2008; Pušić Pajvančić-Cizelj 2012) (Fig. 2).

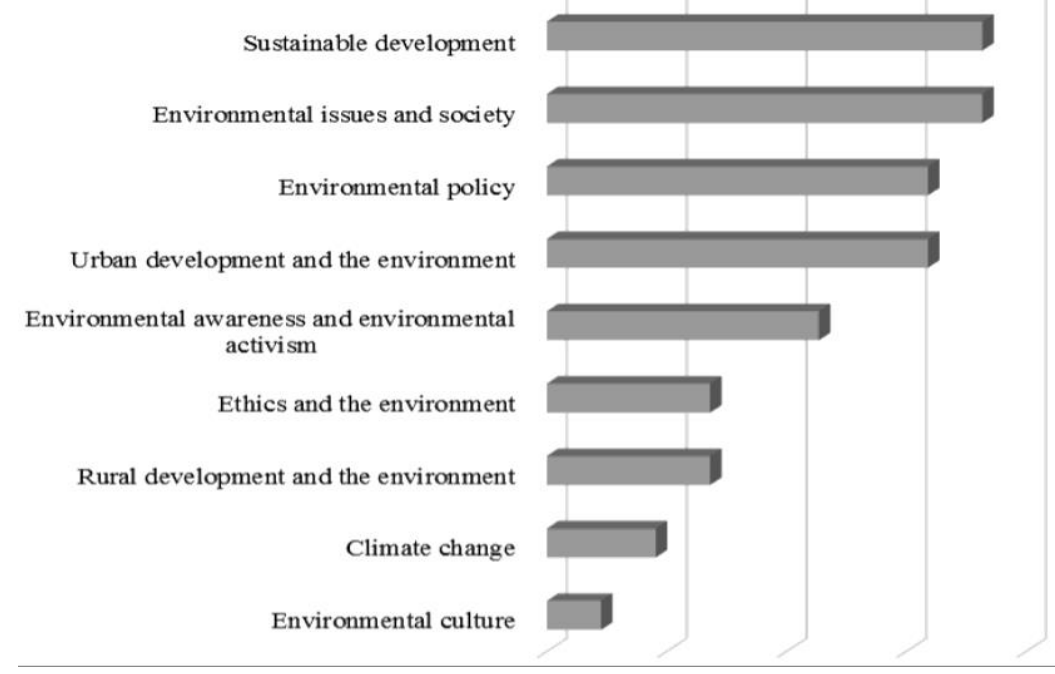

Fig. 2 Key topics of sociological studies

\footnotetext{
${ }^{9}$ Bohr and Dunlap identified 25 key topics published in sociological journals included in the SSCI list: Environmental Concern, Climate \& Society, Environment \& Society, Political Economy, Agriculture, Environmental Inequality, Values, Attitudes \& Behavior, Natural Resources, Social Theory, Policy \& Planning, Governance, Local Environment, Social Movements, Politics, Risk \& Risk Perception, Political Ecology, Demography, Sustainability, Health \& Wellbeing, Development, Tourism, Emissions, Gender, Culture (2018, 181-195).
} 
Environmental policy and urban development and the environment were the next most frequent topics. The papers focusing on environmental policy emphasize the importance of local, national, and international participants in the creation and implementation of environmental policy and different concepts of its creation (see e.g. Nadić 2006; Vuković 2008a; Nadić 2012; Petrović M. 2012a). Urbanization and environmental protection came into focus in the 1990s, paving the way for their various aspects to be examined in the papers by urban sociologists at the beginning of the $21^{\text {st }}$ century (see e.g. Naumovic 1994; Mirkov 2012; Petrović M., Toković 2016).

Environmental awareness, as a prerequisite for resolving any issues concerning the naturesociety relationship, was examined theoretically and empirically. The link between quality of life and environmental awareness was emphasized, with special focus given to the studies of people's perception of environmental issues, their environmental awareness in urban/rural environments, and environmental activism as a major manifestation of environmental awareness (see e.g. Pajvančić \& Markov 2011; Šarković, Cvejić, Bogdanov 2016; Mirkov 2016).

Ethics and the environment and rural development and the environment are ranked fourth according to their frequency in the analyzed papers. The papers dealing with ethics and the environment focused on deep ecology, bioethics, ecocentrism, and anthropocentrism (see e.g. Đorđević 2002; Mišković 2016). The papers dealing with rural development and the environment discussed the relationship between modern agricultural practices and environmental issues, emphasizing the importance of the environmental dimension for the development of rural areas (see e.g. Mitrović M. 1994; Janković 2012).

Climate change and environmental culture were the least discussed topics in the analyzed papers (see Cvetković, Tomašević, Milašinović 2019; Ilić Krstić, Živković, \& Milutinović 2019; Miltojević 2002).

A comparison of the topics examined by sociologists in the analyzed domestic journals with the key sociological topics discussed in leading foreign journals regarding the naturesociety relationship and the current national and international socio-political situation suggests that sociologists in Serbia should give more attention to the study of the nature-society relationship. The possible fields of study include the following: structural changes and protection of the environment; climate change and society; influence of formal and informal education on the acceptance of environmental and ethical principles; environmental awareness and pro-environmental behaviour; rural development and agriculture within the context of sustainable development; environmental culture; citizens' participation in the creation and implementation of environmental policy; social movements and environmental protection; and inequalities and the environment (natural resources).

\section{CONCLUSION}

Based on the presented results, which should be considered preliminary, as a more comprehensive conclusion would require analyzing not only the leading social science journals, but all the others as well, including monographic publications and conference proceedings, this author is inclined to believe that the following statement by professor Ljubinko Pušić is still valid after ten years: "[...] sociology manifested all signs of indifference towards the new intra-disciplinary changes pertaining to the 'matters of the environment", while "some social sciences, such as psychology, economics, political 
science, law, and philosophy, and even pedagogy, have seized the opportunity and began to integrate the "matters of the environment' into their subject of study" (Pušić 2009, 31).

Insufficient interest in SES issues and sustainable development and the prevalent share of authors from non-sociology-specialized faculties can be explained by two facts. First, there is the late introduction of courses such as Social Ecology or Environmental Sociology at the sociology departments of the faculties of philosophy (FOP). Most authors of the analyzed papers were from the University of Novi Sad and the University of Belgrade, whereby sociologists from the FOP in Novi Sad have a longer tradition of dealing with environmental topics, primarily thanks to professor Ljubinko Pušić and the early introduction of Environmental Sociology in the pre-ECTS undergraduate syllabus of the Department of Sociology. In contrast, the FOP in Kosovska Mitrovica introduced the course Social Ecology and the FOP of the University of Belgrade introduced Environmental Sociology in their basic academic studies later, for their first ECTS accreditation in 2009. The FOP of the University of Niš was the last to introduce an environmental course, specifically Social Ecology, but only as a master academic studies course, even though professor Miomir Naumović from the Niš Department of Sociology published a paper on the topic as early as in 1994. Second, thanks to professor Danilo Ž. Marković, the course Social Ecology was introduced at other faculties, such as teacher training faculties, the Faculty of Political Science, and some faculties from the field of technical and technological sciences.

In addition to the aforementioned reasons, it appears that the lack of interest among sociologists is also aided by the fact that public policy makers insufficiently acknowledge the findings from sociological studies, including findings from a small number of studies dealing with environmental issues. Assuredly, sociologists have plenty to offer in terms of solutions for the problems in the man-society-nature relationship. With their theoretical considerations and empirical studies, highlighting how the way of living, production, and consumption are linked with the future directions of development, they can offer, if not definitive, then at least partial, answers to the challenges of modern society, environmental issues, and sustainable development. In this author's humble opinion, the establishment of special environmental branches in Serbian sociological associations and the organization of separate environmental sessions in sociological conferences would help promote sociological research of the socio-ecological system and sustainable development and help impose the inclusion of sociologists in public policy development.

Acknowledgement: This research was financed by the Ministry of Education, Science and Technological Development of the Republic of Serbia (Contract no. 451-03-68/2020-14/200148).

\section{REFERENCES}

Bogdanović, Marija. "Thirty Years of the Journal 'Sociology' - Recollections of Former Editors-in-Chief”. Sociologija 2 (1989): 215-217. [In Serbian]

Bohr, Jeremiah, and Riley E. Dunlap. "Key Topics in environmental sociology, 1990-2014: Results from a computational text analysis". Environmental Sociology 2 (2008): 181-95. https://doi.org/10.1080/23251042. 2017.1393863

Buttel, Frederick H. "Environmental sociology: A new paradigm?". The American Sociologist 4 (1978): 252256. https://www.jstor.org/stable/27702342 (Accessed August 20, 2020)

Carson, Rachel. Silent Spring. Boston: Houghton Mifflin, 1962. https://www.kobo.com/us/en/ebook/silentspring (Accessed August 18, 2020) 
Catton, William R., and Riley E. Dunlap. "Environmental Sociology: A New Paradigm". The American Sociologist 1 (1978): 41-49. https://www.jstor.org/stable/27702311 (Accessed August 20, 2020)

Cifrić, Ivan. Social Ecology. Zagreb: Globus, 1989. [In Croatian]

Commoner, Barry. The Closing Circle: nature, man, and technology. New York: Alfred A. Knopf, 1971. https://www.scribd.com/read/447963969/The-Closing-Circle-Nature-Man-and-Technology (Accessed August 18, 2020)

Cvetković, Vladimir M., Katarina S. Tomašević, and Srđan M. Milašinović. "Security Risks of Climate Change: Case Study of Belgrade”. Sociološki pregled 2 (2019): 596-5626. Doi: 10.5937/socpreg53- 22371

Čikić, Jovana. "Ecological Modernization Theory as a Sociological Framework for Environmental Problem Analysis". Teme 2 (2012): 545-560. [In Serbian]

Dunlap, Riley E. "Paradigms, Theories, and Environmental Sociology". In Sociological Theory and the Environment. Classical Foundations, Contemporary Insights, edited by Riley E. Dunlap, Frederick H. Buttel, Peter Dickens, and August Gijswijt, 329-349. Lanham, Boulder, New York, Oxford: Rowman \& Littlefield Publishers, INC, 2002.

Đorđević, Jelena J. "New environmental ethics and environmental protection". Teme 2 (2002): 235-244. [In Serbian]

Ehrlich, Paul R., and Ehrlich, Anne H. Population, Resources, Environment: Issues in Human Ecology. San Francisco: Berkshire, W.H. Freeman and Company, 1970. file://C:/Users/vesna/AppData/Local/Temp/104.pdf (Accessed August 18, 2019)

ESA. Report on the First European Conference of Sociology. 1992. https://www.europeansociology.org/sites/default/ files/public/Report_on_the_First_European_Conference_of_Sociology.pdf. (Accessed August 18, 2019).

ESA. Second European Conference for Sociology. Fusion or fission. https://www.europeansociology.org/ sites/default/files/public/Fusion_or_Fission_-_2nd_European_Conference_for_Sociology_1995.pdf. (Accessed August 18, 2019)

Golubović, Zagorka. (1989). "Thirty Years of the Journal 'Sociology' - Recollections of Former Editors-inChief”. Sociologija 2 (1989): 207-209. [In Serbian]

Gross, Matthias. Biannual report 2015-2017 to the European Sociological Association, RN 12, "Environment and Society." 2017. https://www.europeansociology.org/sites/default/files/RN12\%20BIENNIAL\%20REPORT\% 202015-2017.pdf. (Accessed August 18, 2019)

Hardin, Garrett. “The tragedy of the commons”. Science 162 (1968): 1243-1248. Doi: 10.1126/science.162.3859.1243 (Accessed September 15, 2020)

Ilić Krstić, Ivana, Snežana Živković, and Slobodan Milutinović. "Gender Dimension of Poverty and its Relation to Climate Change Adaptation”. Teme 3 (2019): 769-782. https://doi.org/10.22190/TEME190610047I [In Serbian]

ISA. ISA bulletin no. 29, 1982. https://www.isa-sociology.org/uploads/files/isa-bulletin29.pdf. (Accessed April 28, 2019)

ISA. XIX ISA World Congress of Sociology - Power, Violence, and Justice: Reflections, Responses and Responsibilities. 2018. https://www.isa-sociology.org/uploads/files/isa-wcs2018-program-book.pdf. (Accessed April 28, 2019)

Janković, Dejan. "Ecological Dimensions of Rural Development". Teme 2 (2012): 627-642. [In Serbian]

Magdalenić, Zlatko. "Toward a Sociological Understanding of the Sustainable Development". Sociološki pregled 2 (2010): 302-324. Doi: 10.5937/socpreg1002309M [In Serbian]

Marković, Danilo Ž. "Globalism and Danger of Global Ecological Crisis". Teme 2 (2002): 219-234. [In Serbian]

Marković, Danilo Ž. Social Ecology. Beograd: Zavod za udžbenike, 2015. [In Serbian]

McKenzie, Roderick D. "The ecological approach to the study of human community". The American Journal of Sociology 30 (1924): 287-301. http://www.jstor.org/stable/2764963. (Accessed September 16, 2020)

Meadows, Donnela H., Dennis L. Meadows, Jørgen Randers, and William W. Behrens III. Limits to Growth. Zagreb: Stvarnost, 1974. [In Croatian]

Michelson, William H. Man and His Urban Environment: Sociological Approach. Harlow, United Kingdom: Longman, 1976.

Milošević, Božo. "Eco-Management: Between Economy and Nature”. Sociološki pregled 3 (1996): 349-356. [In Serbian]

Miltojević, Vesna. "Culture as a Dimension of Sustainable Development”. Teme 2 (2011): 639-653. [In Serbian]

Miltojević, Vesna. "Ecology - humanism - culture". Teme 2 (2002): 245-260. [In Serbian]

Mirkov, Anđelka. "Urban Social Sustainability: A Concept Analysis". Sociologija 1 (2012): 55-70. Doi: 10.2298/SOC1201055M [In Serbian]

Mirkov, Anđelka. "Quality of life in town: views and actions of inhabitants of certain towns in Serbia". Sociologija 0 (2016): 232-244. Doi: 10.2298/SOC16S1232M [In Serbian]

Mišković, Milan. "Deep Ecology: A Movement and a New Approach to Solving Environmental Problems". Sociološki pregled 2 (2016): 247-266. Doi: 10.5937/socpreg1602247M [In Serbian]

Mitrović, Milovan. "The ecology of the country and agriculture". Sociologija 3 (1994): 325-335. [In Serbian] 
Mitrović, Veselin. "Nanotechnologies and Global Survival". Sociologija 1 (2012): 37-54. Doi: 10.2298/ SOC1201037M [In Serbian]

Nadić, Darko. "Ideology of Green Parties". Teme 3 (2006): 441-455. [In Serbian]

Nadić, Darko. "Importance of Strengthening of the Democratic and Political Capacity in Environmental Policy of Serbia”. Sociologija 1 (2012): 71-86. Doi: 10.2298/SOC1201071N [In Serbian]

Naumović, Miomir S. "Social background of town planning and ecology". Teme 1-2 (1994): 177-185. [In Serbian]

Pajvančić, Ana, and Slobodanka Markov. "The role of the local populace in the development of ecotourism: The views of residents of Vojvodina cities on the Danube". Zbornik Matice srpske za drustvene nauke 1 (2011): 51-67. Doi: 10.2298/ZMSDN1134051P [In Serbian]

Pajvančić-Cizelj, Ana. "Environmental Sociology between Classical Sociological Tradition and The New Ecological Paradigm”. Sociološki pregled 1 (2015): 2-24. Doi: 10.5937/socpreg1501003P [In Serbian]

Park, Robert E. "The City: Suggestions for the investigation of human behavior in the city environment". The American Journal of Sociology 5 (1915): 577-612. https://www.journals.uchicago.edu/doi/pdf/10.1086/ 212433 (Accessed August 28, 2020)

Petrović, Jasmina S., and Vesna D. Miltojević. "Empirical Sociology in Serbia at the Beginning of the $21^{\text {st }}$ Century: A (Self)Critical View". In Sociology in XXI Century: Challenges and Perspectives, edited by Jasmina S. Petrović, Vesna D. Miltojević, and Irina V. Trotsuk, 112-128. Belgrade, Niš: Serbian Sociological Association \& University of Niš, Faculty of Philosophy, 2019.

Petrović, Jasmina. "Methodological Problems in Sociological Journals in Serbia". In A Hundred Years of Sociology in Serbian, vol. 2, Special issue of Sociološki pregled, edited by Slobodan Antonić, 959-1001. Beograd: Srpsko sociološko društvo, 2012. [In Serbian]

Petrović, Mina, and Milena Toković. "Neo-endogenous development and ecological paradox: Case study of six cities in Serbia". Sociologija 0 (2016): 181-209. Doi: 10.2298/SOC16S1181P [In Serbian]

Petrović, Mina. "A Word from the Editor". Sociologija 1 (2012), 1-5. [In Serbian]

Petrović, Mina. "Ecology at the local level: The perception of the key subjects". Teme 2 (2012a): 525-544. [In Serbian]

Pušić, Ljubinko, and Ana Pajvančić-Cizelj. "The Way of Perceiving Ecological Problems by Citizens of Vojvodina: Presentation of Empirical Research". Sociologija 1 (2012): 153-168. Doi: 10.2298/SOC1201153P [In Serbian]

Pušić, Ljubinko. "Environmental Sociology as the Broadest Framework for a Research of the Globalizing Social Reality". Sociološki pregled 2 (2013): 171-187. Doi: 10.5937/socpreg1302171P [In Serbian]

Pušić, Ljubinko. "Environmental sociology in search of its academic and research profile". Sociologija i prostor 1 (2009): 27-42. [In Croatian]

Pušić, Ljubinko. "Is the Idea of Sustainable Development Sustainable?" Teme 2 (2012): 425-442. [In Serbian]

Pušić, Ljubinko. Sustainable City: Toward an Environmental Sociology. Beograd: Nezavisna izdanja Sl. Mašića, 2001. [In Serbian]

Scott, Lauren N., and Johnson, Erik W. "From fringe to core? The integration of environmental sociology". Environmental Sociology 1 (2017): 17-29. https://doi.org/10.1080/23251042.2016.1238027

Šarković, Aleksandra, Slobodan Cvejić, and Natalija Bogdanov. "The environmental awareness of agricultural producers in Serbia: Attitudes and practices". Teme 2 (2016): 729-745. [In Serbian]

Vuković, Milovan. "International Water Disputes and Cooperative Responses to Water Stress". Sociološki pregled 2 (2008): 241-260. Doi: 10.5937/socpreg0802241V

Vuković, Milovan. "Security and environment: How to connect them?" Teme 4 (2008a): 691-712. [In Serbian]

Vuletić, Vladimir, and Dragan Stanojević. "Sociological issues in the first decade of 21st century: Comparative analysis of Serbia and Croatia”. Sociologija 1 (2013): 47-68. Doi: 10.2298/SOC1301047V [In Serbian].

\section{ŽIVOTNA SREDINA TERRA INCOGNITA ZA VEĆINU SOCIOLOGA U SRBIJI}

Pitanje daljeg razvoja društva zaokupljuje pažnju naučnika i stručnjaka različitih profila i sve češće se povezuje sa kapacitetima životne sredine i njenim kvalitetom. Na povezanost i aktuelnost pitanja je ukazano još pre više od četrdeset godina, da bi se godinama kasnije rešenje otelotvorilo u novoj paradigmi društvenog razvoja - održivom razvoju. Polazeći od predmeta istraživanja sociologije i njenog značaja za usmeravanje društvenog razvoja, autorki se nametnulo pitanje u kojoj meri i na koji način se sociolozi Srbije u svojim teorijskim i empirijskim istraživanjima bave pitanjem odnosa društvo-priroda i održivim razvojem kao modelom razvoja koji je prihvaćen na 
globalnom nivou. Osnovu istraživanja činili su publikovani prilozi u vodećim nacionalnim časopisima Srbije u oblasti sociologije i multidisciplinarnih nauka. Prvi nalazi pokazuju da se sociolozi ređe bave životnom sredinom $i$ održivim razvojem $u$ odnosu na poklonike drugih društvenih nauka, recimo pravnike, ekonomiste, psihologe, pedagoge, andragoge. Jedan od razloga relativne marginalizacije istraživanja odnosa društvo - životna sredina sa sociološkog stanovišta, prema mišljenju autorke je relativno kasno uključivanju posebnih socioloških disciplina poput Socijalne ekologije ili Sociologije okruženja u kurikulume studijskih programa sociologa.

Ključne reči: društvo, životna sredina, održivi razvoj, sociolozi, periodika. 